322

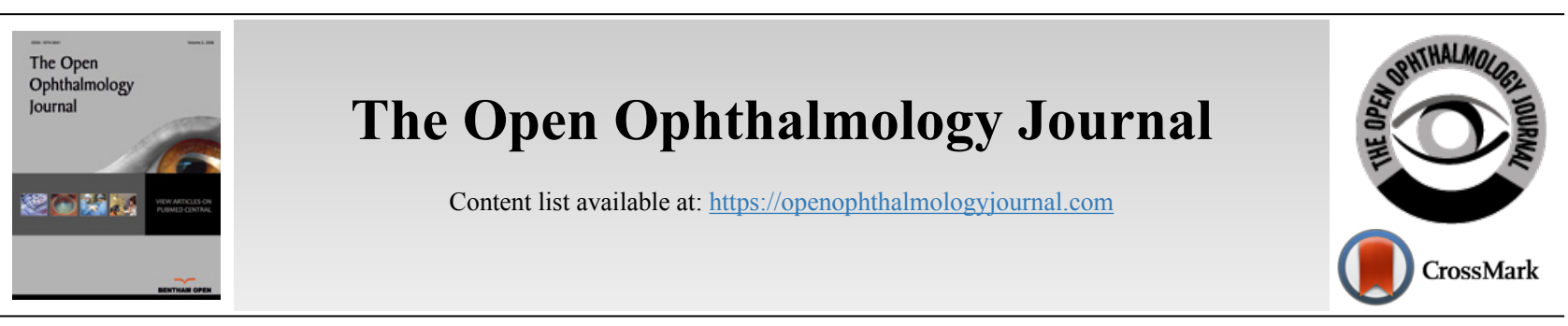

RESEARCH ARTICLE

\title{
Surgical Preferences in the Management of Primary Pterygium among Anterior Segment Specialists
}

\author{
Abdulrahman Alfarhan $^{1,2, *(D)}$, Albanderi Alhamzah ${ }^{2}$, Abdulaziz Abuabat $^{2}$, Tariq Debasi ${ }^{2,3}$ and Tariq Almudhaiyan ${ }^{2,3}$ \\ ${ }^{1}$ King Khaled Eye Specialist Hospital, Riyadh, Saudi Arabia \\ ${ }^{2}$ King Saud bin Abdulaziz University for Health Sciences, Riyadh, Saudi Arabia \\ ${ }^{3}$ Division of Ophthalmology, King Abdulaziz Medical City, Riyadh, Saudi Arabia
}

\begin{abstract}
:
Purpose:

The purpose of this study is to reflect anterior segment specialists' current practice pattern regarding the management of primary pterygium.

Methods:

A 24-item survey regarding indications for surgery, different surgical techniques, use of adjuvant pharmacological therapy, type of intraoperative and postoperative pharmacological therapy, and the preferred treatment of early recurrences was sent to members of the Saudi Ophthalmological Society (SOS) and practicing cornea experts including consultants, specialists, and fellows in Saudi Arabia.

Results:

A total of 61 cornea specialists completed the questionnaire (response rate $49 \%$ ). More than $95 \%$ considered the proximity of the pterygium to the visual axis an indication for excision. The most frequent technique for pterygium excision was extensive head and conjunctival resection, including the base $(69 \%)$ and intermediate resection of the Tenon's capsule $(53 \%)$. For conjunctival replacement, conjunctival autograft was preferred by $79 \%$, amniotic membrane (54\%), and simple conjunctival closure (46\%). Interrupted vicryl sutures, fibrin glue, and combined sutures and tissue adhesive were the preferred graft fixation conveyed by $85 \%, 46 \%$, and $34 \%$ of our experts, respectively. An estimated recurrence rate of $1-5 \%$ was stated by $29 \%$ of respondents and $46 \%$ reported recurrence within 6 to 12 months. Half of the respondents specified using mitomycin C intraoperatively to prevent early pterygium recurrences. When recurrence occurred, corticosteroid was the agent of choice.

Conclusion:

This study set out to reflect the practice pattern of anterior segment specialists regarding the management of primary pterygium, and it may serve as an insight for further studies to define the optimal management of pterygium.
\end{abstract}

Keywords: Preferences, Pterygium, Pterygium recurrence Pterygium surgery, Pterygium technique, Cornea.

\begin{tabular}{l|l|l|l}
\hline Article History & Received: April 17, 2021 & Revised: October 21, 2021 & Accepted: November 08, 2021
\end{tabular}

\section{INTRODUCTION}

Pterygium is a common ocular condition leads to reduced vision and frequent irritation, hence surgical excision is generally indicated for symptom relief $[1,2]$. Although surgical excision can often efficiently improve symptoms, the number of surgical practices existing corroborates the complexity of achieving safe, desirable cosmesis and permanent pterygium removal.

The ideal surgical techniques and rate of recurrence of pte-

\footnotetext{
* Address correspondence to this author at the King Saud bin Abdulaziz University for Health Sciences, Riyadh 14611, Saudi Arabia;

E-mail: Farhan.med011@gmail.com
}

rygium have been debated for several years. New techniques, including graft preparations and post-operative management strategies, have increased tremendously and are helping to reduce recurrence $[1,3]$.

Considering the rapidly evolving literature and the lack of steady data, we aimed to study Saudi corneal surgeons' preferences and current practice in primary pterygium surgical treatment. Results of this study can be beneficial to a better understanding of the surgical options and postoperative course.

\section{MATERIALS AND METHODS}

Approval to this study was granted by the Institutional Review Board of King Abdullah International Medical 
Research Center (KAIMRC) in Riyadh, Saudi Arabia.

The study design was accomplished by utilizing a 24 -item observational survey adopted and approved for use by GraueHernandez et al. [2]. This tool is designed to gather significant information on corneal surgeons' practice patterns. The first nine items in the survey focused on the demographic profile of the participants, and the next subset of questions focused on the indications for surgery, different surgical techniques, use of adjuvant pharmacological therapy, type and duration of postoperative pharmacological therapy, and the preferred treatment of early recurrences. Six minutes was the estimated time to complete the survey and some of the questions allowed for one or more answers.

The survey has been distributed nationally from December 2020 until January 2021 through emails and messages to the members of the Saudi ophthalmological society (SOS) and practicing cornea experts, including consultants, specialists, and fellows in Saudi Arabia.

The data had been analyzed using SPSS Statistics for Windows, Version 24.0 (Armonk, NY: IBM Corp.). Categorical data were presented as frequency and percentages, and numerical data were presented as mean and standard deviation. Pearson's Chi-squared test was used to analyze and compare the distributions of categorical data. A test with a pvalue of less than 0.05 was considered statistically significant.

\section{RESULTS}

Out of 124 anterior segment specialists who received the survey through emails or massages, sixty-one anterior segment experts participated in the survey (response rate 49\%). The majority of the participants were men $(\mathrm{N}=53,87 \%)$. Among the participants, $27(44 \%)$ were under the age of 40, $25(41 \%)$ were between 40 to 49 years, and only $9(15 \%)$ were above the age of 50 . Of respondents, $43 \%$ were based in the Central region of Saudi Arabia, 26\% were in the Eastern Region and $16 \%, 12 \%, 3 \%$ were surgeons in the Western, Southern, Northern regions of Saudi Arabia, respectively. Furthermore, almost half of the respondents were in full-time governmental or academic-based hospitals (49\%), while $23 \%$ and $28 \%$ were in full-time private practice and part-time practice, respectively.

The vast majority of respondents considered the proximity of pterygium head to the visual axis as an indication for surgery in $95 \%$ of their cases. Induced astigmatism, pain/redness, possible dysplastic ocular surface, eye movement restriction, and cosmesis were considered an indication for surgical excision in $93 \%, 88 \%, 85 \%, 82 \%$, and $80 \%$, respectively.

Additionally, 58\% of the respondents do not use any preoperative pharmacological therapy as a medical therapy for pterygium before doing the surgical excision. Nonetheless, $38 \%$ use corticosteroids, $7 \%$ use non-steroidal antiinflammatory drugs (NSAIDs), $5 \%$ use brimonidine, and 19\% apply topical or subconjunctival vascular endothelial growth factor (VEGF) inhibitors.

Two images Fig. (1A and 1B) were provided in the survey to categorize the amount of tissue surgically removed and how much Tenon's capsule they excise. Pterygium excision methods were "extensive head and conjunctival resection including base" (Letter C), "minimal resection of head and conjunctiva" (Letter B), "resect up to the limbus" (Letter A), and "resect extensively up to the caruncle" (Letter D), which were favored by $69 \%, 23 \%, 7 \%$, and $1 \%$, respectively (Table 1). Although not statistically significant $(\mathrm{P}=0.06)$, all surgeons who perform "resection up to the limbus" and/or "resect extensively up to the caruncle" estimated their recurrence rate between $1 \%$ to $5 \%$. While $28.6 \%$ of performing doing "minimal resection of head and conjunctiva" reported less than $1 \%$ of estimated recurrence. Also, $28.6 \%$ of participants performing "extensive head and conjunctival resection including base" method reported an estimated recurrence rate of less than $1 \%$ and 1 to $5 \%$.

Table 1. Pterygium surgical technique.

\begin{tabular}{|c|c|c|}
\hline Variable & No. & (\%) \\
\hline \multicolumn{3}{|l|}{ Tissue removed surgically } \\
\hline Resection up to the limbus & 4 & (7) \\
\hline Minimal resection of head andconjunctiva & 14 & (23) \\
\hline Extensive head and conjunctivalresection including base & 42 & $(69)$ \\
\hline Extensive resection up to the caruncle & 1 & (1) \\
\hline \multicolumn{3}{|l|}{ Resection of Tenon's capsule } \\
\hline Minimum & 19 & (31) \\
\hline Intermediate & 32 & (53) \\
\hline Extensive & 10 & (16) \\
\hline \multicolumn{3}{|l|}{ Conjunctival replacement (one or more answers) } \\
\hline Simple conjunctival closure & 28 & (46) \\
\hline Bare sclera & 3 & $(5)$ \\
\hline Conjunctival autograft & 48 & (79) \\
\hline Limbal-conjunctival autograft & 13 & $(21)$ \\
\hline Buccal mucosa & 0 & 0 \\
\hline Amniotic membrane & 33 & $(54)$ \\
\hline Lamellar corneal / scleral transplants & 0 & 0 \\
\hline \multicolumn{3}{|l|}{ Graft attachment (one or more answers) } \\
\hline Fibrin glue & 28 & $(46)$ \\
\hline Nylon sutures: interrupted & 9 & $(15)$ \\
\hline Nylon sutures: continuous & 0 & 0 \\
\hline Vicryl sutures: interrupted & 52 & $(85)$ \\
\hline Vicryl sutures: continuous & 7 & $(12)$ \\
\hline Biologic adhesives (serum or & 5 & (8) \\
\hline Combined sutures and tissue adhesive & 21 & (34) \\
\hline Electrocautery & 0 & 0 \\
\hline
\end{tabular}

With regards to resection of Tendon's capsule, it was divided into "minimum", "intermediate", and "extensive" with $53 \%$ of respondents selected "intermediate" resection as their method of choice. Besides, "conjunctival autograft" was the most commonly used conjunctival replacement in $79 \%$ of the participants. Moreover, "interrupted vicryl sutures" were the most reported method for graft fixation (85\%), followed by "fibrin glue" in $46 \%$ of the respondents, and "combined sutures and tissue adhesive" in $34 \%$. The remainder of participants' characteristics is shown in Table $\mathbf{1}$.

With regards to intra-operative adjuvants therapy, $57 \%$ of the respondents reported using mitomycin $\mathrm{C}$ (MMC) as the 
most common intraoperative adjuvant pharmacotherapy. Also, all participants reported the use of corticosteroids as postoperative adjuvant pharmacologic therapy (100\%), with $72 \%$ reported prednisolone acetate as their corticosteroid of choice. Furthermore, the findings show some variability in the corticosteroid regimen duration. Less than one-month duration was reported in $21 \%$ of the respondents. However, the majority were prescribed for a duration between 1 to 2 months (72\%). The vast majority reported tapering corticosteroid regimen (90\%).

For recurrence, almost all doctors reported counseling about recurrence prevention by recommending patients to use UV-light blocking glasses at all times when outdoors (98\%). Also, $64 \%$ and $20 \%$ of the participants recommend using frequent lubricating eye drops and adequate sun protection, respectively. The estimated recurrence rate reported by participants is shown in Fig. (2) with $29 \%$ of responses estimated prevalence of recurrence between 1 to $5 \%$. Besides, for the timing of recurrence, $46 \%$ informed a recurrence in 6 to 12 months, $28 \%$ occurred after 12 months, $18 \%$ in less than three months. The prevention of recurrence is displayed in Fig. (3). When early recurrence occurs, a wide variety of methods was reported. Thirty-six percent use corticosteroids as their preferred method.

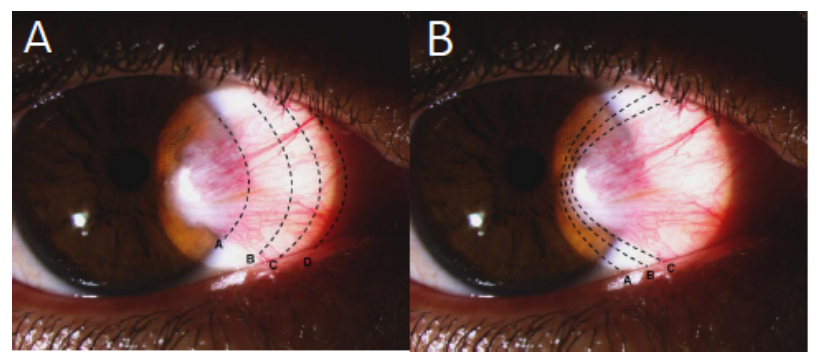

Fig. (1). A, Resection areas. A, Resection up to the limbus. B, Minimal resection of head and conjunctiva. C, Extensive head and conjunctival resection including the base. $\mathbf{D}$, Extensive resection up to the caruncle. B, Tenon capsule removal. A, Minimum. B, Intermediate. C, Extensive.

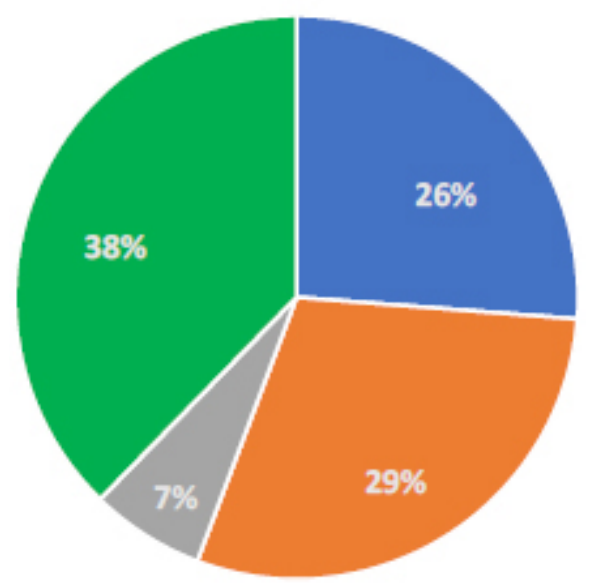

Fig. (2). Respondents edstimated recurrance rate.

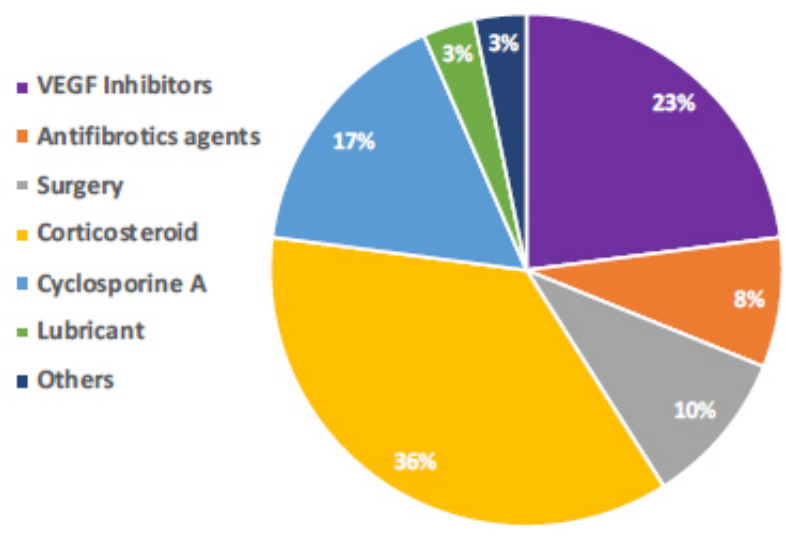

Fig. (3). Treatment of early recurrences.

By comparing the length of experience in performing pterygium surgery, a significant difference was found between surgeons performing pterygium surgery for more than 10 years vs. less than 10 years performers. The findings suggested that surgeons who were performing surgeries for more than 10 years tend to use "Resection up to the limbus/Minimal resection of head and conjunctiva" more often compared to surgeons who were practicing for less than 10 years $(42.9 \%$ vs $11.5 \%$ ). "Extensive head and conjunctival resection including base/Extensive resection up to the caruncle" were favored in those performing pterygium surgery for less than 10 years $(88.5 \%, P=0.008)$. For graft attachment, another significant difference was noticed in "simple conjunctival closure" $(\mathrm{P}=$ 0.002), "conjunctival autograft" $(P=0.025)$, and "Amniotic membrane (AMT)" $(\mathrm{P}=0.002)$. Prednisolone acetate was the preferred corticosteroid of choice for most specialists with less than 10 years of experience $(92 \%, \mathrm{P}=0.002)$; still, $57 \%$ with more than 10 years of experience prefer prednisolone (57\%) (Tables $\mathbf{2}$ and $\mathbf{3}$ ).

\section{DISCUSSION}

Despite the vast literature concerning pterygium, there is still a lack of agreement on the most ideal approach among anterior segment specialists $[1,3,4]$. The surgical techniques currently implied for the treatment of pterygium suggest that recurrence rates are still a dilemma and the ideal treatment has not been identified. We have been able to reflect the current preferences and practices in dealing with pterygium among anterior segments experts in Saudi Arabia.

In this survey, the most common indication for pterygium excision among our experts is the proximity of the pterygium head to the visual axis in 95\%. Induced astigmatism, pain/redness, possible dysplastic ocular surface, eye movement restriction, and cosmetic have been reported as an indication for surgical removal in $93 \%, 88 \%, 85 \%, 82 \%$, and $80 \%$, respectively. This is in agreement with previous reports by Graue-Hernandez et al. [2], Iveković et al. [4], and Lindsay et al. [5]. Diminished vision may occur due to an actual invasion of the visual axis, or a peripheral distortion that induces astigmatism that is hemi-meridional on the side of the pterygium.

Preoperative pharmacological therapy was not used as an 
early treatment before the surgical excision among $58 \%$ of our surgeons. On the other hand, some reported the use of corticosteroids, antibiotics, NSAIDs, brimonidine, and applying topical or subconjunctival VEGF inhibitors in 38\%, $11 \%, 7 \%, 5 \%$, and $19 \%$, respectively. Non-surgical management might deliver some comfort, relieve foreign body sensation, and lessen inflammation. They include artificial tears, topical decongestants, topical NSAIDs, and topical steroids [6]. A recent study by Ucar et al. [7] recommends applying brimonidine tartrate before pterygium surgery. Their study evaluated the reduction of conjunctival injection and bleeding in pterygium surgery after the application of preoperative topical brimonidine. Vasoconstrictive effects of brimonidine were noted to cause $60 \%$ reduction of the surface area of blood vessels within 5 minutes and lasted for 20 minutes [7]. Furthermore, some studies have shown that VEGF is increased as part of pterygium pathogenesis [8, 9]. The overexpression of VEGF in pterygium tissue led to the development of anti-angiogenic/anti-VEGF therapy, which can cause regression of blood vessels and thus delay pterygium progression [8 - 10]. Currently, data in the application of subconjunctival bevacizumab in the management of pterygia are not decisive. For example, Nuzzi et al. [10] established that the application of subconjunctival bevacizumab injections, at the dosage of $2.5 \mathrm{mg} / 0.1 \mathrm{ml}$, before and after excision, can be beneficial in averting lesion recurrence after bare scleral surgeries. On the other hand, an Iranian randomized prospective clinical trial by Razeghinejad et al. [11] found that a single intraoperative subconjunctival bevacizumab has no effect on recurrence rate, early postoperative conjunctival injection, lacrimation, photophobia, or healing of corneal epithelial defect after pterygium excision.

Table 2. Surgery technique by experience with pterygium surgery.

\begin{tabular}{|c|c|c|c|c|c|}
\hline \multirow{4}{*}{ Variable } & \multicolumn{4}{|c|}{ Time Doing Pterygium Surgery } & \multirow{4}{*}{$P$-value } \\
\hline & \multirow{2}{*}{\multicolumn{2}{|c|}{\begin{tabular}{|c|}
$<10 \mathrm{yrs}$ \\
$\mathrm{N}=26$ \\
\end{tabular}}} & \multirow{2}{*}{\multicolumn{2}{|c|}{$\begin{array}{c}\geq 10 \text { yrs } \\
N=35\end{array}$}} & \\
\hline & & & & & \\
\hline & No. & $(\%)$ & No. & $(\%)$ & \\
\hline \multicolumn{6}{|l|}{ Tissue removed surgically } \\
\hline Resection up to the limbusý/Minimal resection of head and conjunctiva & 3 & $(11.5)$ & 15 & $(42.9)$ & \multirow{2}{*}{0.008} \\
\hline Extensive head and conjunctivalresection including base/Extensive resection up to the caruncle & 23 & $(88.5)$ & 20 & $(57.1)$ & \\
\hline \multicolumn{6}{|l|}{ Resection of Tenon's capsule } \\
\hline Minimum & 8 & $(30.8)$ & 11 & $(31.4)$ & \multirow{3}{*}{0.138} \\
\hline Intermediate & 11 & $(42.3)$ & 21 & $(60.0)$ & \\
\hline Extensive & 7 & $(26.9)$ & 3 & $(8.6)$ & \\
\hline \multicolumn{6}{|l|}{ Conjunctival replacement } \\
\hline Simple conjunctival closure & 6 & $(23.1)$ & 22 & $(62.9)$ & 0.002 \\
\hline Bare sclera & 0 & 0.0 & 3 & $(8.6)$ & 0.126 \\
\hline Conjunctival autograft & 24 & $(92.3)$ & 24 & $(68.6)$ & 0.025 \\
\hline Limbal-conjunctival autograft & 8 & $(30.8)$ & 5 & $(14.3)$ & 0.12 \\
\hline Amniotic membrane & 20 & $(76.9)$ & 13 & $(37.1)$ & 0.002 \\
\hline \multicolumn{6}{|l|}{ Graft attachment } \\
\hline Fibrin glue or biologic adhesives & 16 & $(61.5)$ & 15 & $(42.9)$ & 0.149 \\
\hline Vicryl or Nylon sutures & 24 & $(92.3)$ & 30 & $(85.7)$ & 0.424 \\
\hline
\end{tabular}

Bold font indicates $P$ value $<0.05$.

Table 3. Intra- and postoperative adjunctive therapy by experience with pterygium surgery.

\begin{tabular}{|c|c|c|c|c|c|}
\hline \multirow{4}{*}{ Variable } & \multicolumn{4}{|c|}{ Time Doing Pterygium Surgery } & \multirow{4}{*}{$P$-value } \\
\hline & \multirow{2}{*}{\multicolumn{2}{|c|}{$\begin{array}{l}<10 \text { yrs } \\
N=26\end{array}$}} & \multirow{2}{*}{\multicolumn{2}{|c|}{$\begin{array}{c}\geq 10 \text { yrs } \\
N=35\end{array}$}} & \\
\hline & & & & & \\
\hline & No. & (\%) & No. & (\%) & \\
\hline \multicolumn{6}{|c|}{ Intraoperative adjunctive therapy (one or more answers) } \\
\hline Corticosteroids & 2 & $(7.7)$ & 4 & $(11.4)$ & 0.628 \\
\hline Mitomycin C & 15 & $(57.7)$ & 20 & $(57.1)$ & 0.966 \\
\hline 5-fluorouracil & 1 & $(3.8)$ & 0 & 0.0 & 0.242 \\
\hline Antifibrotics & 3 & $(11.5)$ & 2 & $(5.7)$ & 0.412 \\
\hline None of the above & 8 & $(30.8)$ & 6 & $(17.1)$ & 0.211 \\
\hline \multicolumn{6}{|c|}{ Postoperative adjunctive pharmacological therapy (one or more answers) } \\
\hline Corticosteroids & 26 & $(100.0)$ & 34 & $(97.1)$ & 0.385 \\
\hline Nonsteroidal anti-inflammatory & 1 & $(3.8)$ & 4 & (11.4) & 0.286 \\
\hline
\end{tabular}




\begin{tabular}{|c|c|c|c|c|c|}
\hline Antibiotics & 26 & $(100.0)$ & 34 & $(97.1)$ & 0.385 \\
\hline \multicolumn{6}{|l|}{ Corticosteroid of choice } \\
\hline Prednisolone & 24 & (92.3) & 20 & $(57.1)$ & \multirow{2}{*}{0.002} \\
\hline Dexamethasone or other & 2 & $(7.7)$ & 15 & $(42.9)$ & \\
\hline \multicolumn{6}{|c|}{ Anti-inflammatory regimen duration } \\
\hline Less than 1 month & 5 & $(19.2)$ & 8 & $(22.9)$ & \multirow{4}{*}{0.781} \\
\hline 1 to 2 months & 20 & $(76.9)$ & 24 & $(68.6)$ & \\
\hline 2 to 3 months & 1 & $(3.8)$ & 2 & $(5.7)$ & \\
\hline More than 3 months & 0 & 0.0 & 1 & $(2.9)$ & \\
\hline Corticosteroid taper & 25 & $(96.2)$ & 30 & $(85.7)$ & 0.176 \\
\hline
\end{tabular}

Bold font indicates $\mathrm{P}$ value $<0.05$.

Noteworthy, this survey determines that the current experts' predilection remains similar to the previously published report included a complete pterygium removal with its base accompanied by an intermediate Tenon's capsule resection [2]. Conjunctival autograft (CAG) was the most commonly favored conjunctival replacement among our corneal specialists $(79 \%)$. Followed by an amniotic membrane (AMT), simple conjunctival closure, and limbal-conjunctival autograft in $54 \%, 46 \%$, and $21 \%$, respectively. The bare scleral technique was used only by a minority $(5 \%)$. More than half of the respondents (57\%) reported using MMC as their preferred adjuvant intraoperative medications. Among the described procedures, the autologous limbal- conjunctival graft technique conquered the lowermost recurrence rates [3, 12, 13]. Also, Hirst et al. [14] reported in 2012 the lowest recurrence rate with $0.1 \%$ using the "Pterygium Extended Removal Followed by Extended Conjunctival Transplantation (P.E.R.F.E.C.T.)" technique. A meta-analysis that investigated recurrence rates after bare sclera resection with and without MMC use and CAG placement in surgery for primary pterygium found that the odds for pterygium recurrence are close to 6 and 25 times higher if no $\mathrm{CAG}$ placement is performed or if no intra/postoperative MMC is used, respectively [15]. On the other hand, Walkow et al. [16] evaluated bare sclera technique and they found significantly low recurrence rates $(2.9 \%)$ with the use of MMC and phototherapeutic keratectomy (PTK). Similar results were also published by Avisar et al. [17] using the bare sclera technique when they reported that a 5 minutes application of MMC was associated with a recurrence rate of $2.7 \%$ ( 2 out of 74 patients) after 12 months follow-up. However, the implications of these findings are versatile, as with a low recurrence rate, it is statistically inappropriate to conclude a necessary follow-up date [16]. Additionally, a systematic review and network meta-analysis by Zeng et al. [18] concluded that adjuvants such as MMC and bevacizumab could successfully prevent recurrence after pterygium removal. However, MMC has been associated with multiple undesired complications such as scleral necrosis, corneal perforation, cataract, glaucoma, photophobia, and pain [19]. The risk of the development of a complication increases in the high dose and long-time use of MMC [12, 19]. Furthermore, incorporating limbal stem cell in the autograft after pterygium excision has been discussed in the literature. It showed better outcomes in terms of cosmetic appearance and has less recurrence rate as compared to amniotic membrane transplantation. In addition, it was not associated with any major complications postoperatively and it was effective in different grades of pterygium [20, 21].

A recent randomized clinical trial by Prajna et al. [22] disclosed that the recurrence rate of pterygium was significantly higher with the application of AMT than CAG (P $=0.005)$. Similarly, Clearfield et al. [23] showed that AMTtreated eyes had almost double the recurrence rate of CAGtreated eyes at 6 months. Nevertheless, More than half of our surgeons $(53 \%)$ reported the use of amniotic membrane (AMT (as conjunctiva replacement for primary pterygium surgery. Despite the available data, it is possible that some surgeons would rather wait for more evidence and long-term data that back up the absolute superiority of CAG over other methods. In addition, Amniotic membrane could be more useful in particular cases with no viable conjunctiva or when conjunctiva needed to be saved for potential other surgeries [3].

The most common preferred graft fixation method is interrupted vicryl sutures, chosen by the majority, followed by the fibrin glue as the second most common. Numerous studies have favored the use of fibrin glue over suturing due to the lower chance of recurrence, ease of use, less operative time [24]. Though, the suture is still commonly used to fix the conjunctival graft, as it is less expensive and provides an adequate stability, and more widely available [24].

Observing postoperative treatment, the favored agents among our experts were corticosteroids. This survey showed that most participants use potent steroids such as prednisolone acetate or dexamethasone, and usually for a regimen duration of more than one month. Topical steroids can be used to quiet the inflammation and can be tapered slowly. The major side effects of continued steroid use (intraocular pressure increases, steroid-induced cataract formation) must be discussed [25].

The estimated prevalence of recurrences by most surgeons in this survey was $1 \%$ to $5 \%$, which is extremely low in comparison with the recurrence rates established previously in the literature [26]. This might be owing to the experience and expertise of the respondents, but they too can be because of the absence of follow-up for a year. Also, the most common techniques chosen had lesser recurrence rates, as mentioned earlier, complete removal of pterygium with its base accompanied by an intermediate Tenon's capsule resection and the use of MMC. Furthermore, for the timing of recurrence, $46 \%$ of the respondents informed that the most probable time of recurrence was within 6 to 12 months, $28 \%$ occurred after 12 months, $18 \%$ in less than three months. This is consistent with a previous study by Hirst et al. [27], who showed that 
$50 \%$ of recurrences occur during the first 4 months after surgery.

Our data suggested statistically significant differences when surgical techniques were compared by the length of experience with pterygium surgery. These results are similar to an earlier survey study where they found that surgeons with more experience tend to remove less Tenon's capsule, taper corticosteroids less often, and use less fibrin glue and more of sutures for graft fixation than do less experienced ophthalmologists [2].

Despite the valuable data that can be attained from our results, it is crucial to reflect its limitations. As with all surveybased observational studies, participant's answer can possibly be influenced by their recall bias. Therefore, the findings of this study only reflect participant's practice patterns, not the conclusions of a prospective longitudinal study.

\section{CONCLUSION}

Our study presents the current practice preferences of local anterior segment specialists in the management of primary pterygium. Results of this study may be helpful to guide ophthalmologists to define the ideal management of pterygium.

\section{LIST OF ABBREVIATIONS}

$$
\begin{array}{ll}
\text { SOS } & =\text { Saudi Ophthalmological Society } \\
\text { KAIMRC } & =\text { King Abdullah International Medical Research Center } \\
\text { NSAIDs } & =\text { Non-Steroidal Anti-Inflammatory Drugs } \\
\text { VEGF } & =\text { Vascular Endothelial Growth Factor } \\
\text { MMC } & =\text { Mitomycin C } \\
\text { AMT } & =\text { Amniotic Membrane } \\
\text { CAG } & =\text { Conjunctival Autograft }
\end{array}
$$

\section{ETHICS APPROVAL AND CONSENT TO PARTI- CIPATE}

This study was approved by the Institutional Review Board of King Abdullah International Medical Research Center (KAIMRC) in Riyadh, Saudi Arabia. Protocol number: (RC20/598/R).

\section{HUMAN AND ANIMAL RIGHTS}

No animals were used in this research. All human research procedures followed were in accordance with the ethical standards of the committee responsible for human experimentation (institutional and national), and with the Helsinki Declaration of 1975, as revised in 2013.

\section{CONSENT FOR PUBLICATION}

Informed consent was obtained from all the participants.

\section{STANDARDS OF REPORTING}

STROBE guidelines and methodologies were followed for this study.

\section{AVAILABILITY OF DATA AND MATERIALS}

The data supporting the findings of the article is available in Zenodo Repository at https://zenodo.org/record/5593169\#.YXLh0dlBx_Q, reference number [5593169].

\section{FUNDING}

None.

\section{CONFLICT OF INTEREST}

The authors declare no conflict of interest, financial or otherwise.

\section{ACKNOWLEDGEMENTS}

Declared none.

\section{REFERENCES}

[1] Janson BJ, Sikder S. Surgical management of pterygium. Ocul Surf 2014; 12(2): 112-9.

[http://dx.doi.org/10.1016/j.jtos.2014.01.001] [PMID: 24725323]

[2] Graue-Hernandez EO, Córdoba A, Jimenez-Corona A, et al. Practice patterns in the management of primary pterygium: A survey study. Cornea 2019; 38(11): 1339-44.

[http://dx.doi.org/10.1097/ICO.0000000000002091] [PMID: 31403528]

[3] Hovanesian JA, Starr CE, Vroman DT, et al. ASCRS Cornea Clinical Committee. Surgical techniques and adjuvants for the management of primary and recurrent pterygia. J Cataract Refract Surg 2017; 43(3): 405-19.

[http://dx.doi.org/10.1016/j.jcrs.2017.03.002] [PMID: 28410726]

[4] Iveković R, Mandić Z, Sarić D, Sonicki Z. Comparative study of pterygium surgery. Ophthalmologica 2001; 215(6): 394-7. [http://dx.doi.org/10.1159/000050895] [PMID: 11741102]

[5] Lindsay RG, Sullivan L. Pterygium-induced corneal astigmatism. Clin Exp Optom 2001; 84(4): 200-3.

[http://dx.doi.org/10.1111/j.1444-0938.2001.tb05026.x] [PMID: 12366316]

[6] Mauro J, Foster CS. Pterygia: pathogenesis and the role of subconjunctival bevacizumab in treatment. Semin Ophthalmol 2009; 24(3): 130-4.

[http://dx.doi.org/10.1080/08820530902801106] [PMID: 19437347]

[7] Ucar F, Cetinkaya S. The results of preoperative topical brimonidine usage in pterygium surgery. J Ocul Pharmacol Ther 2020; 36(4): 234-7.

[http://dx.doi.org/10.1089/jop.2019.0085] [PMID: 32105500]

[8] Aspiotis M, Tsanou E, Gorezis S, et al. Angiogenesis in pterygium: study of microvessel density, vascular endothelial growth factor, and thrombospondin-1. Eye (Lond) 2007; 21(8): 1095-101.

[http://dx.doi.org/10.1038/sj.eye.6702495] [PMID: 16823458]

[9] Jin J, Guan M, Sima J, et al. Decreased pigment epithelium-derived factor and increased vascular endothelial growth factor levels in pterygia. Cornea 2003; 22(5): 473-7.

[http://dx.doi.org/10.1097/00003226-200307000-00015] [PMID: 12827055]

[10] Nuzzi R, Tridico F. Efficacy of subconjunctival bevacizumab injections before and after surgical excision in preventing pterygium recurrence. J Ophthalmol 2017.

[http://dx.doi.org/10.1155/2017/6824670]

[11] Razeghinejad MR, Hosseini H, Ahmadi F, Rahat F, Eghbal H. Preliminary results of subconjunctival bevacizumab in primary pterygium excision. Ophthalmic Res 2010; 43(3): 134-8. [http://dx.doi.org/10.1159/000252980] [PMID: 19887878]

[12] Hacioğlu D, Erdöl H. Developments and current approaches in the treatment of pterygium. Int Ophthalmol 2017; 37(4): 1073-81. [http://dx.doi.org/10.1007/s10792-016-0358-5] [PMID: 27664148]

[13] Kaufman SC, Jacobs DS, Lee WB, Deng SX, Rosenblatt MI, Shtein RM. Options and adjuvants in surgery for pterygium: a report by the American Academy of Ophthalmology. Ophthalmology 2013; 120(1): 201-8.

[http://dx.doi.org/10.1016/j.ophtha.2012.06.066] [PMID: 23062647]

[14] Hirst LW. Recurrence and complications after 1,000 surgeries using pterygium extended removal followed by extended conjunctival transplant. Ophthalmology 2012; 119(11): 2205-10. 
[http://dx.doi.org/10.1016/j.ophtha.2012.06.021] [PMID: 22892149]

[15] Sánchez-Thorin JC, Rocha G, Yelin JB. Meta-analysis on the recurrence rates after bare sclera resection with and without mitomycin $\mathrm{C}$ use and conjunctival autograft placement in surgery for primary pterygium. Br J Ophthalmol 1998; 82(6): 661-5.

[http://dx.doi.org/10.1136/bjo.82.6.661] [PMID: 9797669]

[16] Sinha R, Sharma N, Vajpayee RB, Rodrigues EB. Long-term results after bare sclera pterygium resection with excimer smoothing and local application of mitomycin C. Cornea 2006; 25(6): 757-8. [2].

[http://dx.doi.org/10.1097/01.ico.0000224633.64686.0c] [PMID: 17077677]

[17] Avisar R, Gaton DD, Loya N, Appel I, Weinberger D. Intraoperative mitomycin $\mathrm{C} 0.02 \%$ for pterygium: effect of duration of application on recurrence rate. Cornea 2003; 22(2): 102-4.

[http://dx.doi.org/10.1097/00003226-200303000-00003] [PMID: 12605040]

[18] Zeng W, Liu Z, Dai H, et al. Anti-fibrotic, anti-VEGF or radiotherapy treatments as adjuvants for pterygium excision: a systematic review and network meta-analysis. BMC Ophthalmol 2017; 17(1): 211. Epub ahead of print

[http://dx.doi.org/10.1186/s12886-017-0601-5] [PMID: 29178848]

[19] Rubinfeld RS, Pfister RR, Stein RM, et al. Serious complications of topical mitomycin-C after pterygium surgery. Ophthalmology 1992; 99(11): 1647-54

[http://dx.doi.org/10.1016/S0161-6420(92)31749-X] [PMID: 1454338]

[20] Soliman Mahdy MAE, Bhatia J. Treatment of primary pterygium: role of limbal stem cells and conjunctival autograft transplantation. Eur J Ophthalmol 2009; 19(5): 729-32.

[http://dx.doi.org/10.1177/112067210901900507] [PMID: 19787589]

[21] Hussain SA, Haider Shaheen K, Ullah MS, Furqan A. Recurrence of pterygium after pterygium excision with stem cell graft and amniotic membrane graft: A comparison. Cureus 2020; 12(1): e6535. [E-pub ahead of print]

[http://dx.doi.org/10.7759/cureus.6535] [PMID: 32038893]

[22] Prajna NV, Devi L, Seeniraj SK. Keenan JDPrajna NV, Devi L, Seeniraj SK, Keenan JD. Conjunctival autograft versus amniotic membrane transplantation after double pterygium excision. Cornea 2016; 35: 823-6.

[http://dx.doi.org/10.1097/ICO.0000000000000812]

[PMID: 27055214]

[23] Clearfield E, Barbara S. Hawkins ICKElizabeth Clearfield, Barbara S. Hawkins ICK. Conjunctival autograft versus amniotic membrane transplantation for treatment of pterygiu. Am J Ophthalmol 2017; 176: 139-48.

[24] Romano V, Cruciani M, Conti L. Fibrin glue versus sutures for conjunctival autografting in primary pterygium surgery. Cochrane Database Syst Rev 2016.

[http://dx.doi.org/10.1002/14651858.CD011308.pub2]

[25] Frucht-Pery J, Solomon A, Siganos CS, Shvartzenberg T, Richard C, Trinquand C. Treatment of inflamed pterygium and pinguecula with topical indomethacin $0.1 \%$ solution. Cornea 1997; 16(1): 42-7.

[http://dx.doi.org/10.1097/00003226-199701000-00009] [PMID: 8985633]

[26] Campagna G, Adams M, Wang L, Khandelwal S, Al-Mohtaseb Z. AlMohtaseb ZCampagna G, Adams M, Wang L, Khandelwal S, AlMohtaseb Z. Comparison of pterygium recurrence rates among different races and ethnicities after primary pterygium excision by surgeons in training. Cornea 2018; 37(2): 199-204. [http://dx.doi.org/10.1097/ICO.0000000000001453]

[PMID: 29176451]

[27] Hirst LW, Sebban A, Chant D. Pterygium recurrence time. Ophthalmology 1994; 101(4): 755-8.

[http://dx.doi.org/10.1016/S0161-6420(94)31270-X]

[PMID: $8152771]$

\section{(C) 2021 Alfarhan et al.}

This is an open access article distributed under the terms of the Creative Commons Attribution 4.0 International Public License (CC-BY 4.0), a copy of which is available at: https://creativecommons.org/licenses/by/4.0/legalcode. This license permits unrestricted use, distribution, and reproduction in any medium, provided the original author and source are credited. 